\title{
Marburg Virus Disease
}

National Cancer Institute

\section{Source}

National Cancer Institute. Marburg Virus Disease. NCI Thesaurus. Code C84883.

A viral infectious disorder caused by Marburg virus. Signs and symptoms include fever, headache, myalgias, chest and abdominal pain, jaundice, liver failure, massive hemorrhaging, and multiple organ failure. 